\title{
THE INFLUENCE OF TAXATION KNOWLEDGE AND TAX AWARENESS ON UMKM TO TAXPAYER COMPLIANCE IN THE SPECIAL PROVINCE OF YOGYAKARTA
}

\author{
Hari Kusuma Satria Negara1 \\ Dian Indri Purnamasari ${ }^{2}$ \\ Universitas Pembangunan Nasional Veteran Yogyakarta \\ Harikusuma05@gmail.com \\ Indri_ntc@yahoo.com
}

\section{A R T I C L E I N F O \\ Article history: \\ Received : 9 September 2018 \\ Revised : 23 September 2018 \\ Accepted : 29 October 2018}

Key words:

UMKM, taxation, compliance, taxpayer.

DOI:

https://doi.org/10.33508/rima.v1i2.2594

\begin{abstract}
A B S T R A C T
The aim of this research to examine whether there is an influence of Taxation Knowledge and Tax Awareness on UMKM to Taxpayer Compliance in the Special Province of Yogyakarta. By using the mail survey method, in the period of the study, respondents who returned and were ready to be analyzed were 163 respondents, namely entrepreneurs or UMKM taxpayers in Yogyakarta. All respondents according to the criteria required in this study and ready to be analyzed, namely having NPWP, UMKM turnover, final income tax payment of $1 \%$, and domiciled in Yogyakarta. The results showed that there was no effect of tax knowledge variables on tax compliance, but there was an effect of tax awareness variables on tax compliance.
\end{abstract}

\section{INTRODUCTION}

In Indonesia, MSMEs have proven to be able to play a role as a safety valve for the national economy during a crisis, and have become a dynamic economic growth after the disaster. However, the magnitude of potential tax sector revenue is not directly proportional to tax revenue. And this is due to the noncompliance of the UMKM taxpayer. The tax sector's amount of income is not encouraging compared to the potential tax revenue in Indonesia. From 2011-2013, the tax sector's revenue only realized an average of $96 \%$ of the existing potential. In 2013, the taxation sector's revenue was far from the possibility, namely only $91.31 \%$. (Mahfud et al., 2017).

In June 2018, the Government launched a new policy on taxation of MSMEs as stipulated in PP No. 23 of 2018. The tax rate applicable to MSMEs in the PP was $0.5 \%$ and entered into force as of 1 July 2018. This policy aimed to stimulate business MSMEs, encouraging community participation, and taxation knowledge (Tatik, 2018). The perpetrators of Micro, Small and Medium Enterprises (MSMEs) in DIY have only around 25 percent, aka still minimal, who pocket a Taxpayer Identification Number (NPWP). This condition results in the difficulty of developing its business. The awareness of 800,000 MSMEs in DIY to obey the tax rules still needs to be encouraged and improved.

SMEs still consider taxation a separate specter for the development of their businesses. In fact, by pocketing NPWP, SMEs can develop faster. Not a few of the UMKM partners require NPWP to work with them. SMEs still claim to be reluctant to be bothered with tax matters when they already have a TIN. They are unwilling when told to make a report until the sanctions they receive when they are late in reporting it. Rather than complicated reporting and the threat of sanctions, not a few MSMEs choose not to take care of NPWP. With the new rules related to MSME tax more than 0.5 percent, hopes that more and more MSMEs will be more obedient to the laws and obedient to pay taxes 
because the previous tax payment rules for MSMEs of 1 percent of the turnover was considered quite burdensome for some MSMEs (krjogja.com).

Previous research by Harsinto and Sarsiti (2017) states that tax knowledge has a positive effect on taxpayer compliance. So the results of the study, Fernando and Arisman (2014), say that tax knowledge has no impact on taxpayer compliance. Then research conducted by Sihombing (2017) states that taxpayer awareness has a positive effect on taxpayer compliance. While the results of Syaiful's research (2016) state that knowledge of taxpayers does not affect taxpayer compliance. A study conducted by Asfa and Meiranto (2017) states that the tax authorities have a positive effect on taxpayer compliance. While the results of Tiraada's research (2013) state that the tax authorities' attitude does not affect tax compliance.

Based on some of the results of previous studies, this study wants to empirically test whether there is an influence of Tax Knowledge and Tax Awareness on the Compliance of UMKM Taxpayers in the Special Province of Yogyakarta.

\section{LITERATURE REVIEW}

\section{Taxpayer Compliance}

Obedience means obeying or obeying teachings or rules. So tax compliance can be interpreted as subject to, follow, and obey taxpayers in carrying out their taxation rights and obligations following applicable tax laws (Rahayu, 2010). Safitri Narmantu said that tax compliance could be defined as a condition where taxpayers fulfill all tax obligations and implement tax rights (Narmantu in Rahayu, 2010).

According to the Big Indonesian Dictionary, the term obedience means to obey or obey the teachings or rules. Tax compliance, according to Devano and Rahayu (2006), is obedience. Be submissive and obedient and implement tax provisions. In tax, the applicable rule is the taxation law. So, tax compliance is someone's compliance, in this case, is the taxpayer, to tax regulations or laws. Taxpayer compliance (Wahyu, 2008) is a taxpayer who is willing to fulfill his tax obligations following applicable rules without the need for examinations, careful investigation, warnings or threats, and the application of sanctions both legal and administrative. Taxpayer compliance is assessed from a situation where taxpayers fulfill all their tax obligations and rights. Such as filling in the correct amount of tax owed, paying taxes on time without any coercive action, and entering and reporting by the stipulated time and delivering information following applicable tax regulations (Utomo, 2011).

From the above statement, it can be concluded that taxpayer compliance is a condition where taxpayers fulfill all tax obligations and implement tax rights. The attitude of taxpayers who have responsibility is not just a fear of sanctions, the applicable tax law, and taxpayers who submit their tax returns on time.

\section{Taxation Knowledge}

According to the Big Indonesian Dictionary, Knowledge means everything known, intelligence, or everything that is known regarding matters (subjects) (Kumadji et al. 2014). Concerning taxation, knowledge is everything about the concept of general provisions in the field of taxation, the types of taxes that apply in Indonesia ranging from tax subjects, tax objects, tax rates, tax calculation owed to how to fill tax reporting (Fermatasari, 2013). Khasanah (2014) states several concepts of tax knowledge, including knowledge of general provisions and tax procedures, knowledge of the taxation system in Indonesia, and about the function of taxation. Sanctions are adverse penalties for people who break the rules, so it can be said that taxation sanctions are penalties for people who violate tax regulations.

According to Erawati (2017), Tax knowledge is the ability or a taxpayer to know tax regulations both about the tax rates based on the laws they will pay and the tax benefits that will be useful for their lives. The 
knowledge of taxation will help taxpayer compliance in paying taxes, so the level of respect will increase.

Knowledge is the result of human experience about something, or all human actions to understand a particular object that can be tangible goods either through reason can also be understood as an ideal object of the human form, or concerned with psychiatric problems. Taxes are people's contributions to the state treasury based on the law (which can be forced) by not getting lead services that could directly show and used to pay public expenses (Mardiasmo, 2009). Tax knowledge is the taxpayer's ability to know tax regulations both about tax rates based on the laws they will pay and tax benefits that will be useful for their lives (Utomo, 2011).

\section{Tax Awareness}

Taxation awareness itself, according to Muliari and Setiawan (2011), is a condition that someone knows, recognizes, respects, and obeys the applicable tax provisions and has the sincerity and desire to fulfill their tax obligations. Awareness of taxpayers' importance of paying taxes for the nation will help improve taxpayer compliance to pay taxes correctly, entirely, and on time. This tax awareness can be increased by understanding the taxpayers of taxation regulations and taxation laws that include taxation procedures that will help taxpayers to know how to fulfill their tax obligations. Awareness of taxpayers of the importance of fulfilling their tax obligations to contribute to the development of the nation and state is fundamental in increasing taxpayer compliance. (Muliari and Setiawan, 2011).

According to Nasution (2003), Taxpayer awareness is the attitude of taxpayers who have understood and are willing to carry out their obligations to pay taxes and have reported all of their income without being hidden following applicable regulations. From the statement above, it can be concluded that tax awareness is a condition where taxpayers know and understand tax matters. Knowledge of taxpayers is essential. If the taxpayer has been aware of paying taxes, taxpayer compliance will be fulfilled so that tax payments will continue to increase, and no more taxpayers are reluctant to pay taxes.

\section{Hypothesis Development}

Effect of Taxation Knowledge on Taxpayer Compliance

Based on the Theory of Reasoned Action (TRA), knowledge is a reason for taxpayers to comply with taxation rules. Excellent experience will lead to an attitude in behavior because they know the impact of the action. Official (2009) states that knowledge of tax regulations is a process whereby taxpayers know about taxation. It will implement in the obligation to pay taxes and know about General Provisions and Tax Procedures (KUP), which include how to make tax payments, place of payment, deadline for paying fines, and SPT reporting.

Mintje (2016) research results show that the relationship between tax knowledge affects taxpayer compliance. Thus, from the explanation, it can be concluded that tax knowledge can help taxpayers carry out their tax obligations. Therefore the hypothesis that will be tested in this study are:

H1: Tax knowledge affects taxpayer compliance.

\section{Effect of Tax Awareness on Taxpayer Compliance}

Based on the Theory of Reasoned Action (TRA), awareness to comply with taxes is a behavior that has a positive impact. Taxpayers believe the results of this behavior have a positive effect. This is unified with the Theory of Planned Behavior (TPB), where there are control beliefs related to the individual's intention. If the taxpayer has high behavioral control of the awareness of paying taxes, then the will to conduct taxcompliant behavior also will be high. Tax awareness is a condition where someone knows, acknowledges, respects, and obeys the applicable tax provisions and has the sincerity and desire to fulfill their tax 
obligations (Muliari and Setiawan, 2011).

Awareness in paying taxes is community service, which is part of the country. The higher the level of taxpayer awareness, the better understanding and implementation of tax obligations to increase compliance (Muliari and Setiawan, 2009). If there is an awareness of taxpayers, obedience, obedience, and discipline will emerge (Lestari et al., 2016). Taxpayers who are aware that taxes are obligations that must be paid will increase compliance in paying taxes.

Mintje (2016) research results show that the relationship between tax awareness affects taxpayer compliance. Thus, from the explanation, it can be concluded that tax awareness can help taxpayers in carrying out their tax obligations. Therefore the hypothesis that will be tested in this study are: compliance

H2: Tax awareness affects taxpayer

Conceptual Framework

Figure 1: Conceptual Framework

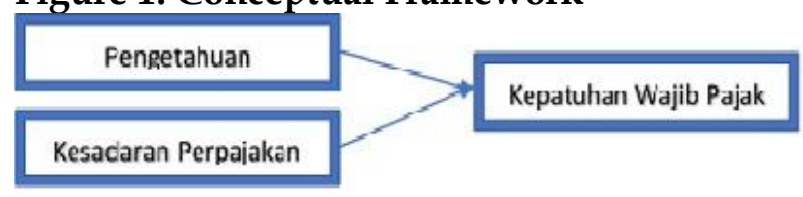

\section{METHODOLOGY}

Population and Sample

In compiling this research, the method used is quantitative research methods. According to Sugiyono (2012), quantitative research methods can be interpreted as a research method based on the philosophy of positivism. This method used to examine specific populations or samples, sampling techniques generally carried out randomly, data collection using research instruments, quantitative or statistical data analysis with the goal is to test a predetermined hypothesis. The object of this research is UMKM Taxpayer in Yogyakarta Special Region.

In quantitative research methods, research methods that can be used are survey research. The survey method is used to get data from a particular place that is natural (not artificial). Still, researchers conduct treatment in data collection, for example, by distributing questionnaires, tests, structured interviews, and so on (treatments not as in experiments) (Sugiyono, 2012). This research method of data collection techniques using a questionnaire as a research instrument.

\section{Variable Operations}

Taxpayer compliance is defined as the behavior of taxpayers who refer to the level of respect in fulfilling tax obligations, both in calculating, depositing, and reporting tax payable. This variable can be measured by four indicators that the Taxpayer is said to be obedient if he has a score above the average rating. The questionnaire used is data processed by researchers obtained from research sources Ayuningtyas (2017).

Taxation Knowledge is the ability to know tax regulations based on the law (Jatmiko, 2018). The knowledge of taxation will help taxpayer compliance in paying taxes, so the level of respect will increase (Erawati, 2017). Indicators for tax knowledge variables cited from Jatmiko's research (2018) are the Ability to know tax regulations based on the law.

Tax Awareness is the behavior of taxpayers in the form of views or perceptions that involve beliefs, knowledge, and reasoning and a tendency to act following the stimulus provided by the applicable taxation system and provisions (Ritongan, 2011). Indicators used in tax awareness variables are quoted from Gresandi's research (2018), namely: perceptions of taxpayers (Statements numbers 1, 2, and 3) and characteristics of taxpayers (Statements numbers 4 and 5). We are using a four-point Likert scale, 1-4.

\section{RESULT AND DISCUSSION}

Pilot Test

Before the questionnaire was given to real respondents, researchers conducted a pilot test to determine the instrument's validity and reliability, avoid unclear questions, different perceptions of the issues, 
and know the time needed to fill out the questionnaire. The pilot test was conducted on 30 respondents consisting of Masters in Management students, with consideration and assumptions that they had worked, had an income, and had a TIN. The results of the pilot test are as follows:

Table 1. Pilot Test Results

\begin{tabular}{|l|c|c|}
\hline \multicolumn{1}{|c|}{ Variabel } & $\begin{array}{c}\text { Cronbach } \\
\text { Alpha }\end{array}$ & Notes \\
\hline $\begin{array}{l}\text { Pengetahuan } \\
\text { Perpajakan }\end{array}$ & 0,821 & Reliabel \\
\hline $\begin{array}{l}\text { Kesadaran } \\
\text { Perpajakan }\end{array}$ & 0,761 & Reliabel \\
\hline $\begin{array}{l}\text { Kepatuhan Wajib } \\
\text { Pajak }\end{array}$ & 0,836 & Reliabel \\
\hline
\end{tabular}

The results of the Pilot Test test table showed that with 30 Master of Management students overall, the questions in this questionnaire were reliable. Research with four variables, namely tax knowledge, tax awareness, and tax compliance, is reliable for all items. Likewise, the validity test shows that the overall questions on each variable correlate significantly with a significance level of $5 \%$, so they are valid.

\section{Data analysis}

In the study period, 163 respondents returned and were ready to be analyzed, namely the MSME taxpayer or businessman in Yogyakarta. All respondents following the criteria required in this study and prepared to be analyzed, namely having NPWP, UMKM turnover, final income tax payment of $1 \%$, and domiciled in Yogyakarta.

\section{Hypothesis Testing and Discussion}

Table 2. Hypothesis Testing Results
\begin{tabular}{|l|l|r|r|r|}
\hline \multicolumn{1}{|c|}{ Coefficients $^{\mathrm{a}}$} & \multicolumn{1}{c|}{$\begin{array}{c}\text { Unstandardized } \\
\text { Coefficients }\end{array}$} & $\begin{array}{c}\text { Standardized } \\
\text { Coefficients }\end{array}$ & $\mathrm{t}$ & \multirow{2}{*}{ Sig. } \\
\hline \multirow{3}{*}{ Model } & \multicolumn{1}{|c|}{$\mathrm{B}$} & Std. Error & Beta & \\
\hline \multirow{3}{*}{1} & (Constant) & 14.849 & 1.811 & \\
& Pengetahuan Perpajakan & .108 & .061 & .161 \\
& Kesadaran Perpajakan & .023 & .087 & .025 \\
\hline a. Dependent & Variable: Kepatuhan & & & \\
\cline { 2 - 5 } &
\end{tabular}

Hypothesis testing results indicate that the taxation knowledge variable statistically shows a result $>0.05$, which means that it is not significant or the hypothesis is rejected. The results show there is no influence of the tax knowledge variable on taxpayer compliance. Knowledge of taxation possessed by taxpayers was not able to increase or even affect taxpayer compliance. This is not under the results of previous studies. This is very likely to occur because of several things, including knowledge that is very likely to be standard without education and awareness of tax risks. It is even possible that taxpayers feel MSMEs with a small turnover that does not affect the target sector and state revenue from taxes. The taxpayer only knows tax knowledge without any implications for carrying out his taxation obligations.

Hypothesis testing results indicate that the tax awareness variable statistically shows results $<0.05$, which means that a significant or accepted hypothesis suggests there is an influence of tax awareness variables on tax compliance. These results are consistent with some of the effects of previous studies and show that when taxpayers have tax awareness, it will be followed by taxpayer compliance. Taxpayers are aware of all tax rights and obligations, even aware of the risk of non-compliance with taxation so that it makes taxpayers obedient to taxation. 


\section{CONCLUSION}

The results of this study concluded that:

1. There is no influence of tax knowledge variables on tax compliance.

2. There is an influence of tax awareness variables on tax compliance.

\section{Limitations and Suggestions}

This study has several limitations, including the number of respondents who have not represented the total number of MSME taxpayers in Yogyakarta and have not been divided into several KPP Pratama areas. So in subsequent studies, researchers extend the period of research time, in collaboration with the tax office, especially in the helpdesk, which many taxpayers visit.

\section{REFERENCES}

Anggara, A. B. 2017. Kepatuhan Pajak Usaha Mikro, Kecil, Dan Menengah Di Surakarta. Jurnal Akuntansi. Universtas Islam Indonesia.

Asfa, Esti R.; Wahyu M. 2017. Pengaruh Sanksi Perpajakan, Pelayanan Fiskus, Pengetahuan dan Pemahaman Perpajakan, Kesadaran Perpajakan Terhadap Kepatuhan Wajib Pajak. Diponegoro Journal Of Accounting, 6(3), 1-13.

Boediono, B. 2003. Pelayanan Prima Perpajakan. Jakarta: Rineka Cipta.

Boediono, B. 2011. Pelayanan Prima Perpajakan. Jakarta: Rineka Cipta

Cahyadi, I Made Wahyu., I Ketut Jati. 2016. Pengaruh Kesadaran, Sosialisasi, Akuntabilitas Pelayanan Publik, dan Sanksi Perpajakan pada Kepatuhan Wajib Pajak Kendaraan Bermotor. E-Jurnal Akuntansi Universitas Udayana, 16, 2342-2373.

Devano, S., \& Rahayu, S. K. (2006). Perpajakan: Konsep, Teori, dan Isu. Kencana, Jakarta.

Fernando; Arisman, Anton. 2014. Pengaruh Sosialisasi Perpajakan, Pengetahuan
Perpajakan, dan Sanksi Perpajakan Terhadap Kepatuhan Wajib Pajak Orang Pribadi. Jurnal Akuntansi. STIE Multi Data Palembang.

Gardina, Trisia; Haryanto, Dedy. 2006. Analisis Faktor-Faktor Yang Mempengaruhi Kepatuhan Wajib Pajak.Modus, Vol. 18 (1), hal. 10-18.

Ghozali, Imam. 2018. Aplikasi Analisis Multivariate Dengan Program SPSS 29.

Semarang: Badan Penerbit Universitas Diponegoro.

Harsinto, P.; Sarsiti. 2017. Pengaruh Pengetahuan Perpajakan Dan Pengenaan Sanksi Terhadap Kepatuhan Wajib Pajak Usaha Mikro Kecil Dan Menengah (UMKM) Di KPP Pratama Boyolali. Jurnal Penelitian dan Kajian Ilmiah Fakultas Ekonomi Universitas Surakarta, 15(4).

Hendri, Nedi. 2016. Faktor-faktor Yang Mempengaruhi Kepatuhan Wajib Pajak Dalam Membayar Pajak Pada UMKM Di Kota Metro. AKUISISI, 12(1). Jurnal Fakultas Ekonomi. Universitas Muhammadiyah Metro.

Ira. 2018. Kesadaran Pajak UMKM di DIY Masih Rendah. https:/ / www.krjogja.com. Diakses pada 9 Desember 2018.

Laraswati, M.; Siti N. \& Hendro S. 2017. Pengaruh Pemahaman Sistem E-Billing, Kualitas Pelayanan, Dan Pelaksanaan Sanksi Pajak Terhadap Kepatuhan Wajib Pajak UMKM Mebel Di Kabupaten Sukoharjo. Makalah dipresentasikan di Seminar Nasional IENACO.

Mardiasmo. 2009. Perpajakan. Edisi Revisi. Penerbit Andi Offset. Yogyakarta.

Mardiasmo. 2011. Perpajakan: Edisi Revisi 2011. Yogyakarta: Andi. 
Mintje, M.S. 2016. Pengaruh Sikap, Kesadaran, Dan Pengetahuan Terhadap Kepatuhan Wajib Pajak Orang Pribadi Pemilik (UMKM) Dalam Memiliki (NPWP). Jurnal EMBA, 4(1), 1031-1043.

Muliari, N.K. dan Setiawan, P.E. 2010. Pengaruh Persepsi Tentang Sanksi Perpajakan Dan Kesadaran Wajib Pajak Pada Kepatuhan Pelaporan Wajib Pajak Orang Pribadi di Kantor Pelayanan Pajak Pratama Denpasar Timur. Jurnal Akuntansi Dan Bisnis: Fakultas Ekonomi Universitas Udanaya.

Nasution, Chairuddin Syah. 2003. "Analisis Potensi Dan Pertumbuhan Penerimaan Pajak Penghasilan (PPh) Di Indonesia Periode 1990 - 2000". Kajian Ekonomi Dan Keuangan, Vol. 7, No. 2.

Nurmantu, Safri. 2010. Pengantar Perpajakan. Jakarta: Kelompok Yayasan Obor

Paramartha, I Putu Indra. 2016. Pengaruh Kualitas Pelayanan, Pengetahuan Dan Sanksi Perpajakan Pada Kepatuhan Wajib Pajak Badan. Jurnal Akuntansi, 15 (641 666). Universitas Udayana.

Rahayu, Nurulita. 2017. Pengaruh Pengetahuan Perpajakan, Ketegasan Sanksi Pajak, Dan Tax Amnesty Terhadap Kepatuhan Wajib Pajak. Jurnal Akuntansi. Universitas Sarjanawiyata Tamansiswa.

Resmi, Siti. 2017. Perpajakan: Teori dan Kasus. Edisi 10. Yogyakarta: Salemba Empat.

Santoso, Wahyu. 2008. Analisis Risiko Ketidak Patuhan Wajib Pajak Sebagai Dasar Peningkatan Kepatuhan Wajib Pajak: Penelitian Terhadap Wajib Pajak Badan Di Indonesia. Vol 5, Nomer 1.

Siahaan, Marihot Pahala. 2010. Hukum Pajak Elementer, Konsep Dasar Perpajakan Indonesia. Yogyakarta: Graha Ilmu.
Siti Kurnia Rahayu, 2010. Perpajakan Indonesia: Konsep dan Aspek Formal, Yogyakarta: Graha Ilmu.

Situmorang, Patricia M.B. 2017. Pengaruh Kesadaran Wajib Pajak dan Penerapan EFiling Terhadap Kepatuhan Wajib Pajak. Jurnal Administrasi Bisnis. Universitas Diponegoro.

Sujaweni, V. Wiratna. 2016. Implementasi Penentuan Harga Pokok Produksi Untuk Mencapai Laba Optimal (Studi Pada Sentra UKM Industri. 